수술직후를 지탕하조 나가기는 그리 힘늘지 않는데 그이유는 그통안 산소를 충분히 공급 하게 되고, 또 여러가지 호홉보조기관을 사용 할수 있기 때문이다. 오히려 문제는 수술을 받은후 장기간후에 폐조직에 어떠한 기질적변 화가 이러나며, 이것이 그사람의 호흡기능에 어떠한 영향을 주는가하는 점이다.

지금 미국에서 임상적으로 제일 많이 사용 되고 있는 것은 계시적 페활량측정법(Timed Vitalometry)이다. 이것은 보통 페활량기에 게시장치를 하여 측정할수도 있고. 또 호흡측 정기(Spirometer)의 곡선을 가지교 측정할수 도 잇는데 그목적은 총폐활량과 동시예 1.2.3 초동안의 총페활량의 몇\%를 그 환자가 내숼 두 있는가를 아는 것이다. 보롱사람에 있어서는 총량의 $83 \%, 94 \%, 97 \%$ 를 1.2 .3 초내에 내숼 수 있다. (Comroe et al) (1) 그러나 기도에 협착이 있는 환자, 즉 폐기종(Emphysema) 환자 같은 때는 기관지협착 의한 저항으로 인하여, 그가치가 뗘러지게 된다. Miller(2) 는 한걸음 더 나아가 이것을 $0.5,075,10$ 초.로 구분하고. 있는데 그에 의하면 호홉시, 그유효 환기(Effective Ventilation)가 0:5초내에 이 러난다는 것이다. 보롱사람의 0.5 초 페활량은 $60 \%$ 이상이다. 따라서 총페활량은 환기능력의 기계 적제한을 말하고, 시간적 페활량은 기도 내의 협착유무를 말한다.

이상의 방법으로 결정이 균난할 때에는 최 대호흡능력 (Maximum Breathing Capacity) 잔량(Residual Volume) 측정, 동맥산소량측 정, 감별적흐홉측정 (Differential Bronchospirometry) 동을 행하게 된다.

경헙상으로버아 이같은 복잡한 검사는 일반 적으로 필요없고, 구술받는 환자의 $80 \sim 90 \%$ 는 임 상적소견과 간단한 계시적 폐활량측정으 로 고호홉기능은 알수있다.

\section{3) 사각림파선검사(Scalene Node Biopsy)}

이림파선은 전사각근근복윙i 있는 것으로 방기관림파선계 (Paratracheal L. N. Chain) 의 직접연창이조 따라서 훙곽내질환 특히 폐 질환이 립파계롱운 따라 외부로 나을때 제일
먼저 도달하는 곳이다. 따라서 진단을 나리기 곤난할때 소위 맹목적검사(Blind Biopsy)를 하여 페내에 있는 질환을 진단한수 있는 일이 많고 $(20-30 \%)$ 또 기관지암에는 이것을 하 여 암이 페외로 전이하였는가 아닌가를 반견 하여 수술가부를 결정하는 일이 있다. 이것은 국소마취하에 간단히 할수 있다.

\section{II. 기관지암 (폐암) Bronchogenic Carcinoma}

오늘 세계적으로 기관지암과 같이 세인의 주목을 그는 병은 없을 것이다. 즉 과거이는 이겻이 드믄 병의 하나였는데 지금에 와서는 이것이 악성신챙물중 제일 많고 이것은 미국 과 영국의 통계를 보면 알수 있다. 미국에 있 어서 1938-1948년 사이여 다른 암의 증가는 $31 \%$ 임에 비하여 기관지암의 증가는 $144 \%$ 연 고 또 영국에서는 동기간 내에 다른 암 $22 \%$ 증가에 비하여 이것은 $122 \%$ 증가이다. 이것이 사실적인 증가인지 또는 진단방법의 발전과 훅곽의과의 발전으로 인한 의관상의 것인지를 막론하고 숫자적으로 증가의 길울 걸고 있는 것이 사실이며 따라서 이에대한 관심과 대책 이 없을수 없다.

이렇게 관심과 일종의 공포심이 증가함에 따라 이에 대한 조기진단이 중요하기 되는데, 역시 제일 중요한것은 의사의 마음속에 기관 지암에 대한 관심이 있음은 물론 환자에게도 이것을 인식시키는 것이다. 특히 40 이 넘은 남자예 있어서 호홉기병이 오랫통안 낫지않는 다거나 또는 $\mathrm{X}$ 선사진상 의심스러운 소견이 있 울때에는 이것이 암이 아니라는것이 증명될때 까지 추궁하여야 될것이다. 즉 DeBakey(3) 의 보고를 브면 대개는 암있는 환자가 40 이상이 고 특히 $90 \%$ 가량이 남자에게 발생하고 있다.

진단방 법중 가장 중요한것은 역시 $\mathrm{X}$ 선 사진 이고, 기간지암의 $75-85 \%$ 를 이렇게 진단할 수 있다. (Ochsner (4), Ariel (5), Gibbons (6)) 어 이의에도 기관지경검사 $(22-57 \%)$, 기관지 분비물의 세포학적검사 $(60-90 \%)$, 기관지조 영출, 폐동맥촬영솔, 천자조직검사, 사각림파 선검사등이 있다. 이상의 방법으로 진단을 
확실히 할수 없고, 그러나 기관지암의 의심이 있을빼는 시험개훙을 하게 되는데 이것은 점 점 미국내에서 보편화되고 있다. 그 이유는 기관지암의 증가에 따라 이에 대한 공포심이 많은 한펀 대개 이러한 경우에는 암이 적은범 위에 국한되어 절제할수 있고 또 절제후 장기 챙 존률이 많기 때문이다.

기관지암의 치료는 절제밖에 없다. 병이 진 행되어 절제할수 없는 환자에게는 $\mathrm{X}$ 선 요법 Nitrogen mustard. 「라디움 J주입 등을 하지만 이것은 쓸수있는 분량에 제한이있고 또 부작 용때문에 일시적방도에 지나지 않는다.

Shaw 와 Paulson(7) 이 의하면 처음 환자를 보았울때 수술이 가능한수는 전환자의 $50 \%$ 이 고, 또 수술을 하여 절제가 가능한 환자수는 총수의 약 $1 / 3$ 이다. 또 Gibbon(6) 의 경혐도 같다. 수술적 사망률은 폐전적출이 있어서 $11.9 \%$ 페엽절제에 있어서 $2.8 \%$ (환자총수 578)로 되어 있다. (Shaw + Paulson) (8) 이 와같이 폐엽절제시에 사망룰이 적은것은 대개 이러한 환자여 있어서는 병의 진행정도가 심 하지 않기 때문이다.

페절제후 장기생존률에 있어서는 기관지암도 다른 악성신챙물과 갚이 5 년을 표춘으로 한다 대개 수술을 받은후 1 년울 사는 관자는 많지 만, 그후에는 그수가 갑짜기 떠러저서 2 넌이 후에는 그수가 고정되는것이 보통이다. 따라 서 페절제훙 2 년을 사는 환자에게는 5 년을 살 가능성이 많다. 일반적으로 5년 챙존률은 18$20 \%$ 이고 Shaw 와 Paulson (8) 의 숫자는 다 음과 같다. (제 1표)

제1표 외과적 5년생존률(기관지암)

\begin{tabular}{r|r|r|r}
\hline & 수술환자 & 생 존 자 & 생 존률(\%) \\
\hline 케전적출 & 41 & 6 & 15 \\
\hline 케엽절제 & 10 & 2 & 20 \\
\hline 합 계 & 51 & 8 & 15 \\
\hline 한자중수 & 175 & 11 & 6 \\
\hline
\end{tabular}

1) 폐엽절제 대 폐전적출

제 1 표와 같이 제엽절제가 페전적출에 비하 여 그수술사망률이라든지 장기쌩존률이 좋은
것을 알수가 있다. 그러면 과연 숫자상에 나 타난 이대로인가에 대하여 의심하게 되는데, 이것을 명 백히 하기는 험틀것이다. 즉 기판지 암때에 페전적출을 하게 될때에는 대개 암이 페문부위로 침범하였거남, 또는 그렇게 되었 다즈 의심될때이조, 따라서 그절제하는 범위 가 넓을뿐 아니라, 장기챙존률이 나뽄것이 당 연한 일이다. 기관지암이면 덮어놓조 페전적 출을 하여야 되는것은 아닐더이고, 다음의 여 러가지 조건을 참고하여야 할것이다. 또 폐엽 절제어 있어서도, 폐문, 기간지분기부, 방기 관림파선을 동시에 절제할수 있다는 것을 알 어야 된다. 기관지암에 있어서 폐엽절제를 하 게되는 경우는

1, 환자의 폐심기능 (Cardio-Pulmonary Functiom)이 감초되었을때

2. 진단이 불확실하고, 또 폐엽절제로서 그 질환이 전부 제거되리라꼬 생각될때

3. 질환이 적고, 폐말초부에 있을때

4. 기관지암의 범위가 너무 넓어 치유적절 제(Curative Resection)는 할수없으나 방 펀적절제(Palliative Resection)는 할수 있을때 등이다.

\section{2) 고립성원형질환(Isolated Round Lesion)}

이상과갇이 기관지암에 대한 관심이 높아지 고 이에대한 진단과 수술이 발달하였다교는 하나. 그수술가능률이나, 5년생존률은 별로 좋 아지지 못하꼬 있는것이 현상이다. 이것은 주 로 환자기 발병훅 의사를 늦게 찾아오는것과 또 의사가 확실한 진단을 붙이려조 시일을 보 내는데 주요원인이 있다.

따라서 기관지암의 조기진단어 있어서 이조 립성 원형질환(소위 Coin Lesion)이 중쇼성을 떠-ㅇ-게 되는데, 크것은 이러한 질환중의 악성 신생물이 많조, 또 신생물이 아니라도 후에 환자에게 해되는 영향을 줄 질환이 많은 까닭 이다. 이것은 주기적 $\mathrm{X}$ 선검사때에 많이 발견 되는데, 조립성원형질환이라조 하몀 대개

1) 폐야에 그립되어있어 체문과의 접촉이 없울때. 2) 그직경이 $5 \mathrm{~cm}$ 이내일때. 3) 신 
체 다른곳에 원발성신생물이 없을때 이다. 1954년 Meckstroth(9)는 이러한 질환이 있는 환자중 개훙수술을 받은 70 레에 대하여 보고 하였는데 그중 27레 (40\%)이 있어서 악성신 챙 물을 발견하여刃고 그중의 11 레 (15\%)는 기관지 암인것을 보고하엮다. 이것은 보통 보는 숫자 보가는 많지만 좌우간 이것으로보아 열마녀. 이것이 무서운것인가를 알수 있다. 또 1952년 Greenville-Mathers (ii) 는 23 개의 소위 결핵 종(Tuberculoma)에 더하여 보고 하였는데 시일이 감에 따라 점점 커진것이 4 , 공동화 한것이 4 , 공동화한후 다른곳으로 퍼진것이 3 인것을 보았다. 즉 전체의 $50 \%$ 가 악화하였. 다. 이것으로 보아 이것이 암자체 이외베드.

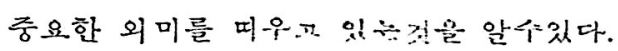

이것을 임 상적으로 진단학기는 극히 힘든다 미국에서 훈히 보는 Coccidioidin, Histoplasmin, Tuberculin 으로하는 피루검사도 믿을 수가 없마는것은 우리가 추측할수 있는바로, 기관지분비물의 세포학적 또는 세균학적검사 도 그리 확실정이 없다. 또 일부예서는 이러 한 질환이 석회화한 부분이 있으면 악성신생 물이 아니라교 하나, 경험상으로 기관지암과 결핵이 공존함을 우리가. 알기때문여 이역시 믿울수 없다.

따라서 진단과 치료를 위하여 유일한 길은 이것을 절제하는 것이다. 수술때에 이것이 악 성이 아니라는 것을 알면 결상절제 (Wedge

Resection)을 하거나 또는 구엽절제 (Segmental Resection)을 하조, 악정이라도 엽절제 로서 될때가 많다. 즉 이질환이 있어서 수술 을 해야되는 이유는 1) 진단을 붇이기 힘든 것. 2) 악성신챙물일 염려가. 많은것. 3) 적 은 범위의 절제가 가능하조 따라서 구술사망 률과 합병증이 적은것. 4) 장기간 챙존률이 좋은것 틍이다.

\section{III. 폐 결 핵}

미국예 있어서 결핵에 의한 사망률은 1900 의 $200: 100,000$ 로 부터 1949 의 $25: 100.000$ 으로 떠러지고 잇다. 그러나 아직 잉i대한 대책어 여러가지가. 강구되조 있는데 특히 페절
제술의 발달과 더부러 결핵치료에 대하여 새 로운 시대를 가저왔다조 볼우 있다. 즉 미국 너어서도 페결핵에 대한 본격적치 료가 시작된 것은 항생제 특히 SM, PAS, INH 의 반견으 로 폐절제술이 안전하게된 추라그 하겠다. 종 전의 훙곽셩형술 기타의 허탈요법이 간접적인 데 비하여 이것은 직접으로 페너질환을 절제 하게 되기때문에 의사나 환자측에 매력을 느 끼게 함은 물론, 그후 치료성적에 있어서 종 래의 치료법에 비하여 우수하다는 점이 알려 지게 되어 현재와 같은 발달은 보게 된것이다.

\section{1) 약물요법}

환자가 으양소에 입 원한후 여러가지 일반검 사를 끌마친후 치료방침을 세우기 전에 회의를 하게된다. 이때이 대략 환자를 두종류로 나누 게 되는데, 즉 앞으로 수술을 받을 가능정이 있는 환자와 그렇지 않은 환자로 구별한다.

불론 이것이 절대적이 아니고, 치료경과에 따 라 번하는일도 있기만 대략 이것으로 치료방 침을 세울수 있다. 수술가능ㅇㅈㅇㅇㅇㅣ 있는 환자 이게는 항생제를 시작할때 횔수있으면 $\mathrm{SM}$ PAS, 또는 INH-PAS을 사-용하고 세가지를 전부 쓴다거니 또는 $\mathrm{SM}-\mathrm{INH}$ 를 쓰지 않기로 한다. 그이유는 환자어 따라서 이러한 항생제 에 대한 저항이 속히 생기는데, 이러한 대에 는 SM, INI 중 한가지를 남겨 두었다가 수술 때예 사용하자는 것이다. 또 수술을 받지않을 환자이] 있어서도 될수 있는한 이방침을 쓰고 있는데, 그것은 경과에 따라 이러한 환자도 수술을 받는것이 좋기 때문이다. 여기서 제의 되는 환자는, 질환이 경하여서 전연 수술받을 필츠가 없는때; 모는 질환이 너무 진행되었거 나, 또는 관자의 전신 상태와 폐기능이 나빠서 전연 수술받을 가능정이 없을때 동인 데 이러 한때이는 세가지를 동시에 사용하거나, 또는 $\mathrm{SM}-\mathrm{INH}$ 를 사-용하는 일도 있다.

수술받울 환지에 있어서는 약물요법울 4-6 개월간 계통적으로 사-옹한훙에 수술을 하게 된 다. 만약 이시기에 환작ㅇㅇ 질환이 X선상으로 계솓하여 조전될 때예는 3개월 더 즉 9개월까 지 기다려 수술하게 되는데 이이상 더 기다려 
수술하는 것은 이상적이 야니조, 그것은 대개 이때가 되면 관의 저항력이 나타나기 때문이 다. 약물요법을 계통적.으로 받지 못하였거나 포는 수술시기를 노친 환자여 있어서 균의 저 항력이 챙겼다조 갱각될때어는 수술기간을 통 하여 Viomycin 라 Terràmycin 을 사용하여 좋은 결과을 보조 있다.

다음에 몇가지 제일 보편적으로 사용되조 따라서 중요하다고 챙각되는 외과적치료법을 들어. 보렸다.

\section{2) 폐절제술}

페결핵치료에 있어서 현재 절제술이 가장 널러 사용되즈 있는 이유는 다음과 같다. 즉 폐기능손실이 적은것, 객담음성전환이 빠른것 수술도수가 적은것, 수술사망률이 흉곽성형술 과 비틍한것(1.5\%)(11), 장기효과가 좋은것 (80\%)(11), 그러그 훙곽기형이 쌩기지 않는 것 이다. 계통적 약물치료와, 구엽절제술어 발달 에 따라, 절제범위는 점차로 적어지고 따라서 환자가 수술훅 일상갱활을 함에있어서 부자유 없이 일을 하게되는 일이 많다.

어떠한 사람이 폐절제 대상이 되는가어 대하 여는 미국전체로 보아 거이 표춘화 되었다조 볼수있는데 즉

1. 약물요법으로 일정한 기간내에 없어지지 안는 공동

2. 기관지협착으로 분비물배설이 막힐 때

3. 결 핵정 기관지확장증

4. 중엽과 하엽의 공동

5. 결핵종

6. 상피화한 공동

7. 허탈쇼법의 실패

8. 파괴된 페 퐁이다

그러낭 이것만 가지즈 전부의 환자을 선랙 하려면 무리가 생길것이고, 그 개인여 따라서 그 요법을 다소 변경하는 경우도 갱길것이다, 페절제를 반는 환자는 대부분이 젊은 사람 이기 때문어 특수한 경-우를 제의하그는 복잡 한 흐홉기능검사를 하지안는것이 보롱이다. 그버나 질환이 심하여, 호홉기능의 저하돤 사 람, 포는 연구를 목적으로 하는 때 퐁이는 예
외이다. 한가지 톡히 중요한것은 결핵성기간 지염의 유무를 알어야 되는 것인베 이것은 절 제부위에 활동성 기관지염이 있으면 수술후 합병증 특히 기관지늑막무가 생기기 때문이다 따러서 절제를 받울 환자는 누구나 수술전 일 주일 이낙에 기관지경검사를 받어야 된다.

\section{3) 튱각성형술}

폐절제술의 발달에 따라 훙곽성형술은 차차 그 도수가 적어지고 있는테, 다음표을 보면 알수있다. (제 2 표)

제 2 표 폐절제와 성흉술의 비례 (Shaw and Paulson) (1)

\begin{tabular}{c|c|c|c}
\hline 년 & 1946 & 1949 & 1954 \\
\hline 졔 절제 : 성홍술 & $1: 21$ & $1: 3$ & $2: 1$ \\
\hline
\end{tabular}

이것이 폐절제술에 비하여 그치료성적이 좋 지못하조 따라서 현재 이깃은 폐절제가 불가 능한 환자에 있어서 이용되는일이 많다. 즉 케절제에 비하여 수술적 사망률은 많고(1.8$3.0 \%$ ). (111) (1. 장기간치료성적은 좋지못하다: (64\%), (11) 물론 이것은 성 훙술을 받는 환자의 질환은 좀더 진행된것이 보통이라는 점도 있 겠지만 종합적으로 iㅐㅇ각할때 폐절제만 못한것 은 사실이다.

성훙술에 있어서 종전 대로 7 늑골정훙술-을 하는 도수는 점차로 적어지고, 질환의 정도에 따라 가감하게 되는 일이 많다. 또 이것을 단 독적으로 사용하는 이외에도 페절제와 같이 사용하는 일이 많다. 즉 절제범위가 크리라 생각되는 때에는 수술에 의한 늑막내사강을 제거하기 위하여 절제전 또는 절제와 동시, 또 는 절제후에 부분적 성훙술을 할때가 있다.

이러한 경우에는 제 1 늑골은 남겨두고, 제 2 , 3.4 , 또는 5 까지 절제하.조, 척추횡돌기는 남 겨무는 것이 보통이다.

\section{4) 늑락 괴충전술(Extrapleural Plombage)}

1946년 Wilson(10) 과 1949년 Trent (i. 에 의 하여 보편화된 충전술은 그후 며러 사람에게 채택되어 그 효과이 기대되는 바가 많었으나 
즈후 시일의 경과와 동시에 여러가지 결 점이 발견됨에 따라. 이에 대한 흥미는 식어가는 경향이 있다. 즉 이것은 훙곽성형술과 같은 허 할요법의 일종이나 늑골을 절제하는 대신, 그 낭 남겨두고 늑막외 견갑골하에 여러가지 이 불, 즉 공기, 기름, Plastic Ball 또는 plastic Sponge 등을 넣어 페의 허탈을 기하는것이나 현재 가장 밚이 사-용되고 있는것은 Lucite Ball 이다.

드케내에 이물이 늘어가면 이에 대한 일정 한 병리조직학적 변화가 이러남은 주지하는바 로 이상과 같은 불질도, 자극성이 적다교는 하나, 역시 이불로서의 자극이 없올수 없다. 1954년 Inada (110) 는 충전룰을한 63명중 늑막 외농훙 6(10\%)을 보꼬하옃고, 또 Destorges(11) 는 32 레중, 12 레( $37 \%$ )에 있어서, 견갑골하참 출액으보 부터 결핵균을 배양할수 있었다고 보고하였다. 이외에도 페천공, 충전물의 이동 동통등 여러가지 결점을 들수 있다. 이러한 결점을 없이하려고 최근에는 다른 충전불 측 Ivalon Sponge 같은것을 사용하는 일도 있 으나, 아직 이에 대한 장기적 관찰은 없다.

이충전술은 특히 미국 동부지방에서 많이 사용되교 있고, 중부와 남부에서는 그리 사옹 되지 않고 있는데, 이것을 사옹하는 사람의 주장은 수술도수가 적은것, 폐기능감소가 적 은것, 그리고 수술후 훙곽기형이 없는것 뚱이 다. 저자의 이에 대한 경험은 적으나 일반적으 로 보아 수술후에 몹시 아프고, 또 공동이 잘 없어지지 않었고 따라서 후에 절제술 또는 다 른 재수술을 요하는 경우가 많었다. 따라서 이것은 절제술이나 성훙술이 불가능 또는 곤 난한 겅우에 하는일이 많다.

\section{IV. 기판지확장증}

기관 젓왁장증은 우리가 보통 생각하는것 보 다든 많다. 즉 Lindskog (1)의 보고에 의하면 부검시 전환자의 $2-3 \%$ 는 기관지확장증을 가 기고 있다는 것이다. 임상적으로도 기관지조 영술의 반달과 폐의과의 반전으로 전어 막연 히 만성⿰ㅖㅇ염이나 기간키염으로 진단받교 치료 받어 오던것이 사실인즉 기관지확장증이라드
것이 밝혀치고 있다.

현재 미국에서 기관지확장증에 대하여는 일 반적으로 외과적소법 즉 페절제를 하조 있다. 그렇다고 해서 내과요법이 전연 필요없는것은 아니고, 외과요법과 내과요법이 같이 사옹 됨 으보서 가장 좋은 결과을 기대한샤 있을 것이 다.

내과요법으로는 체 위적 배 담 (Postural Drainage), 기관지경검사와 분비물의 채 집, 세 균 배양과 감수성검사(Sensitivity test). 이에 대한 적당한 항생제의 사용, 기간지확장제와, 객담 용해제의 사용, 단속적양압흐흡기 (Intermittent Positive Pressure Breathing(IPPB))울 이용하게 된다. 륵히 내과요법이 이용되는 경 우는 나이 많은 환자에 있어서, 켸기종과 섬 유화(Fibrosis)가 심할때 또는 병의 범위가 너무 커서 의과적으로 절제할수 없을때 등인 떼 이러한 환자에게 계통적인 내과요법을 시행함 으로서 일상갱활을 편안하게 함은 물론, 일개 사회인으로서 챙활을 할수있게 할수 있다.

IPPB아 기관치확장제, 그러고 객담영해제 는 동시이 사용뵈는데, 이것을 사용함으로서 염 증과 분비물로 인한 기관지경련 (Bronchospa$\mathrm{sm})$ 을 극복하고 또 분비물을 묽게 하여 객출 을 옹이케 한다.

그러나 이러한 치료는 대증적인 방책에 치 나지 않고 기관지내에 이러난 기질적변화를 제거한구는 없다. 기관지확장증은 일단 발생 하면 이것을 다시 정상대로 회복시키지 못하 는 질환이며 따라서 이것을 없이하려면 그 붕 분을 절제하는우 밖에 없타.

기간지확징증은 원칙적으로 구엽적 칠환이 다. 즉 병의 분포가 기관지케구엽(Bronchopulmonary Segment)을 따르게 되조. 따라서 이에 대한 절제는 구엽절제기 많다. 이것은 페결핵과 다른 점인떼 즉 결핵은 원칙적으로 폐실질의 질환이고 따라서 폐구엽의 경계선을 침범하는 일이 많다. 또 한가지 기관지학장증 의 륵이한 점은 이것이 보통 양쪽페 하부에 발생하기 때문에 이것을 절제한다음 남은 페 조직의 위치변환이 반갱하든섯이다. 이역시 상엽니 많이 발챙하르 케결핵과느 다론 점이 
다. 이러한 위치변환으로 인하여 분비눌의 제 거가 힘들게 되그 따라서 이러한 곳에 기관지 확장증이 재발한다고 주장하는 사람도 있다. 한가지 주의할 점은 수술하기 전에 양쪽폐의 완전한 기관지조영술을 하여 수술족뿐이 아니 라 반대측의 상태를 잘 알어야되고 륵히 상엽 도 포함하여 질환이 있는 부분은 전부 절제하 여야 된다. 최근 Overholt (1) 는 상엽의 전구 엽에 있는 질환을 모르고 수술시에 남겨둠으 로서 수술환자의 $8 \%$ 가 재수술을 받게 되었다 고 보고하였다.

외과요법으로 $75-80 \%$ 는 좋은 결과를 얻는 다. (Ginsaierg, (2010 Lindskog) (탕, 수술합병증 은 $11 \%$ 가량이조 특히 중요한것은 농휼(2. $3 \%)$ 기관지늑막루 $(3.6 \%)$ 이다.

\section{V. 폐 농 양}

항생제의 사용과 동시에 폐농양의 수는 굽. 격히 갈소되어 가교있다. 미국에 있어서는 경 제력과 교양정도가 높은 유료환자중벼 는 이것 을 거이 볼수없는 형켠이고, 시료환자나, 호 는 「알롤 J중독자, 정신병자들 중ㅇi 어 이섯을 많이 본다.

이질환도 항생제와 훙막외과의 발달로 급속 한 진보를 보이고 있는베 이것은 다음표를 보 아 알수 있다. (제3표)

제 3 표 폐농양의 치료성전 (Shaw团) (Shaw \& Paulson年)

\begin{tabular}{r|r|r|r}
\hline & 수 술 법 & 좋은결과 & 수술사망룰 \\
\hline 1942 & $\begin{array}{l}\text { 늑골절제과 } \\
\text { 배옹 }\end{array}$ & $57.5 \%$ & $15.2 \%$ \\
\hline 1948 & iㅖ 절 제 & $85.0 \%$ & $3.5 \%$ \\
\hline
\end{tabular}

폐농양의 치료에도 내과와 외과의 두가지가 있다. 내과요법이는 두가지 옥적이 있츤데

1. 내과으법으로 질환의 완전치 유를 도모하 는것-전수료의 약20\%(Shaw) (인

2) 내과요법으로. 주위의 염증변화를 적게하 여 절제를 송이하계 하는것 이다. 내과요법으 로 세균검사와 헝행제의 사형은 눌론, 체위적 배담 기관기겅에 의한 분비눌의 제거와 필요 에 따라, $\mathrm{SK}-\mathrm{SD}$ 의 사형를 하게ㄱㅚㅚㄴㅏㅏ. 특히
이것은 부패성농양(Putrid Abscess)에 중요 한데 그것은 이러한 농양이 대개는 염기성세 균으로 반챙되조. 따라서 이러한 농양과 기관 기사이에 교통이 있어 공기가 드러가게 된다 면, 이것이 직접 세균을 억제하는 작용이 있 기 때꾼이다.

이러한 방법으로 반응이 없을때어는 절제를 하게 되는데 이때에는 보롱 급성기를 지나 주 위와 폐쭌부의 염증이 다 갈아앉은 다음에 하 는것이 수술자체도 쉽고 또 결과가 좋다. (체 4 표)

제 4 표 폐농양에 대한 폐절제

(Shaw.de Paulson) 22)

\begin{tabular}{rrr|r|r}
\hline & & 홓은결과 (\%) & 수술사망률(\%) \\
\hline 급 성 & $ㄱ$ & $82.7 \%$ & $3.8 \%$ \\
\hline 만 & 성 & 기 & $100 \%$ & $0 \%$ \\
\hline
\end{tabular}

포 만약에 적항한 내과요법에도 불구하교 농양내공물이 제거되지 않거나 또는 주위에 염증이 사라지지 않을때에는 늑골절제를 하뇨 홍벽외부로 배옹시켜 염증을 적게하고 또 환 자의 전신상태를 좋게 한다음 절제를 하는 일 도 있다.

\section{VI. 결 롤}

폐외과중 미국예서 현재 시행되고 있늘 중 으한 몇가기만을 소개하었다. 훙곽외과는 아. 직 역사가 짧조 발전도상데 있으며 따라서 앞 으로 촣은 방법이 나타나는데 따라 현재 사옹 되고 있는 여러가지 방법이 없어질 것이다. 이것은 비교적 발달되고 또 표춘화 되었다즈 갱각되는 폐외과 분야세서도 그러하다.

특히 훙곽외과는 다른 분야와 달라 진정한 의미에서속하조 팡범위한 진보가 있으려면 내과외과의 협력은 물론 마취학자 $\mathrm{X}$ 선학자. 페심징iㅐㅇ리학자, 세 균학자등의 절데적인 협력 이 있어야 된다. 이와같이 임 상국분야와 호 임상가 기초의학의 긴밀한 연락이 없이는 훙 곽의과의 발전울 기할수 없을 것이다. 


\section{VII. 문 헌}

1. Comroe, J. H. Jr, Forster, R. E. II, Dubois, A. B., Briscoe, W. A. Carlsen E. ; The Lung : Clinical Physiology and Pulmonary Function Tests. p129. The Year Book Publishers. Inc. Chicago. 1955

2. Mis:, William F.; Personal Communication.

3. DeBakey, M.E., Ochsner, A., DeCamp P.T.; Primary Carcinoma of the Lung. Surgery $32: 8771952$

4. Ochsner, A. , DeBakey, M. E., : Primary Carcinoma of Lung. J. A. M. A. $135: 3211947$

5. Ariel, I. M., Avery, E.E., Kanter, L, Head, J. R. , Langston, H. T. : Primary Carcinoma of the Lung. Cancer $3: 229$ 1950

6. Gibbon, J.H. Jr., Albritten, F.F. Jr, . Templeton, J. F. III. Nealson, T. FJr. : Cancer of the Lung-An Analysis of 532 Consecutive Cases. Annals of Surgery. $138: 489^{\circ} 1953$

7. Paulson, D. L., 'Shaw, R. R. : 'Early Detection of Bronchogenic Carcinoma. J. A. M. A. $146: 5251951$

8. Shaw, R. R.., Paulson, D. L. : Personal Communication.

9. Meckstroth, C. V. et al : Surgery For Solitary Lesions of Lung. A. M. A. Arch. Surg. $59: 2201954$

10. Greenville-Mathere, R. : Natura] History of So-Called Tuberculomas. J. Th. Surg. $23: 2511952$

11. Hughes, F.A., et al: Thoracoplasty and Resection for Pulmonary Tuberculosis. J. Th. Surg. $25: 4541954$

12. Paulson, D. L. : Personal Communication.

13. Mendenhall, E., Shaw, R. R. : Rece- nt Trends in Treatment of Pulmonary Tuberculosis. J. A. M. A. 148: 5951952

14. Wilson, D.A. : The Use of Methacrylate Plombage in the Surgical Treatment of Pulmonary Tuberculosis. Surg. C1. N. Am. 26: 10601946

15. Trent, J.C., et al : An Evaluation of Extrapleural Plombage with Lucite Sphares: Report of Fifty-one Cases. J. Th. Surg. 18: 1731949

16. Inada, I. et a1 : Evaluation of ExtraPleural Pneumonolysis with filling with Plastic Balls: Analytic Studies on 63 Patients from whom Plastic Balls were removed. J. Th. Surg. $27: 503 \quad 1954$

17. Desforges, Gerard, et al: Tuberculous Infections complicating Subcostal Plombage with Lucite Sphares for the Collapse Therapy of Pulmonary Tuberculosis. J. Th. Surg. 28: 6361954

18. Lindskog, G. E,. Liebow, A. A. : Thoracic Suorgery and Related pathology. P 151 Appleton-Century-Crofts. Inc. New York 1953

19. Overholt, R. H., Neptune, W.B.: The Significance of the Anterior Segment in Bronchiectasis. J. Th. Surg. 30: 2881955

20. Ginsberg, R. L., Cooley, J. C., Olsen Arther M. \& Kirklin, John, W. : An Analysis of Unfavorable Results in the Surgical Treatment of Bronchiectasis J. Th. Surg. 30: 3311955

21. Shaw, R.R. : Pulmonary Abscess. J. Th. Surg. 11: 4531942

22. Shaw, R. R. and Paulson, D. L. : Pulmonary Resection for Chronic Abscess of the Lung. J. Th. Surg. $17: 514 \quad 1948$ 


\title{
Current Status of Pulmonary Surgery in the United States
}

\author{
Pill Whoon Hong, M. D. \\ Department of Surgery \\ Severance Union Medical College
}

The rapid progress in the field of Thoracic Surgery throughout the world for tho past 10 years has been unique in the history of surgery.

There are several tactors which have had adeciding influence on the growth of this relatively new branch of medicine. These were development in anesthəsia, systematic use of body fluid replacement, particularly that of whole blood, discovery of antibiolics, understanding of cardiopulmonary physiology and its application to clinical medicine, and finally the refinements in surgical technic. The impetus for this concerted effort was g!ven during the world war II, when a large number of chest traumas among the war casualties had to be handled.

\section{Bronchogenic Carcinoma}

The increase in the incidence of bronchogenic carcinoma in the U.S. has been astounding and alarming. During the 10 year period ending in 1918, the bronchogenic carcinoma increased by $144 \%$ whereas other carcinomas' increase was only $22 \%$. Whether this represents an actual increase in the number of patients or an apparent increase due to better and more thorough diagnostic studies is a matter of some doubt. The consensus today seems to support the former.

Bronchogeenic carcinoma is predomina nt among the male who are in the carcinoma age group. Diagnostic studies should include $\mathrm{x}$-ray studies, bronchoscopy and cytological studies of the bronchial secretions. Special studies include bronchography, pulmonary angiography, aspiration biopsy and scalene node biospsy. The number of exploratory thoracotomy has been steadily increasing because these cases usually represent early stage of the disease and consequently have more chance of a cure.

According to Shaw and Paulson. (7) operability is in the neighborhood of $50 \%$ and the resectability is $33 \%$. The five year survival according to the same authors (8) are $20 \%$ for the lobectomy group and 15\% for the pneumonectomy group.

In connection with the problem of bronchogenic carcinoma is that of isolated round lesion in the lung. Approximately 20 to $40 \%$ of these lesions are malignant neoplasms and these should be handled as such. Various diagnostic studies are of limited value in deciding the exact nature of the disease, and consequently these cases, as a general rule, should be explored.

\section{Pulmonry Tuberculosis}

With the advent of antituberculosis drugs and the progress in the thoracic 
surgery, the treatment of tuberculosis has become more and more surgical with corresponding improvement in overall results. Today the more widely used and accepted prozedures are pulmonary resection, thoracoplasty and extrapleural plombage.

Pulmonary resection :

The generally accepted indications for resection are;

1. Persistent cavity

2. Bronchostenosis

3. Tuberculous bronchiectasis

4. Cavities in the lower lobe

5. Tuberculomas

6. Failure in collapse therapy

7. Destroyed lung

5. Bronchopleural fistula and empyema ,

Prevailing mortality rate in resection is 1.5 to $5 \%$ and good results can be obtained in about $80 \%$ of the resected cases.

\section{Thoracoplasty}

Although extrapleural thoracoplasty has been used less frequenfly than it was before, it is still a useful procedure in selected cases.

In general, it is reserved for those cases in whom a resection does not seem advisable for various reasons. The important factors favoring ihoracoplasty instead of resection are resistence to antituberculosis drugs and wide spread disease. Long term follow ups show that $64 \%$ of the cases do well.

Combination of resection and limited thoracoplasty has been used extensively for some time to obliterate the dead space left by resection. However, the wisdom of this policy is being challenged more and more recently.

\section{Extropleural Plombage}

Different materials have been used to fill the extrapleural space for collapse therapy. the most popular material being used at present is lucite-spheres. The idea of plombage was popularized by wilson (14) and Trent (15). In som: quarters in the U.S. this procedure has deen used quite extensivery. However, accumulating evidence seems to indicate that the complications following this procedure are considerable, chief among them extrapleural tuberculous empyema. Further evaluation seems indicated for this reason.

\section{Bronchiectasis}

The incidence of the bronchiectasis among the general population is greater than is apparent. With the diagnostic aids such as bronchography and bronchoscopy, more cases have been discovered and treated successfully.

The treatment of bronchiectasis is both medical and surgical. Medical treatment include antibiotics, postural drainage, bronchoscopy, bronchodilators, detergents and use of Positive pressure breathings. The surgical treatment of bronchiectasis is mainly resectional. Segmental resection is particularly convenient for this disease because the disease process usually involves one or more bonchopulmonary segments. By operation 75 to $80 \%$ of the cases can expect a good result.

\section{Lung Abscess}

The incidence of lung abscess in the U. S. has been decreasing with discovery 
of antibiotics and also an early and thorough treatment of contributing diseases.

There has been a major' change in the treatment of this disease during the past 10 years, which is directly related with the development of resectional surgery. Whereas a rib resection and cavity drainage was main procedure previously this has been replaced by lung resection.
About $20 \%$ of the entire cases will respond to conservative therapy. It is the prevailing concept in regard to resection that sufficient time be allowed for the surrounding inflammatory process to subside before a resectional surgery is undertaken. About $85 \%$ of those operated cases oblained a good result. 